\title{
UPAYA PROMOTIF DAN PREVENTIF UNTUK MENGURANGI RISIKO YANG DITIMBULKAN OLEH ROKOK DI KELURAHAN RANCAMAYA
}

\section{PROMOTIVE AND PREVENTIVE EFFORTS TO REDUCE RISKS POSED BY CIGARETTES IN RANCAMAYA SUB-DISTRICT}

\author{
Ade Saputra Nasution* \\ Kesehatan Masyarakat, Fakultas Ilmu Kesehatan, Universitas Ibn khaldun, Bogor \\ email: adenasution@uika-bogor.ac.id
}

\begin{abstract}
ABSTRAK
Merokok sudah menjadi kebutuhan dan gaya hidup masyarakat Indonesia, rokok menimbulkan banyak permasalahan bagi perokok itu sendiri bahkan lebih berisiko pada orang yang tidak merokok tapi menghirup asap rokok (perokok pasif). Permasalahan rokok di Indonesia masih menjadi perhatian dari pemerintah namun masih tingginya angka perokok dimulai dari anak-anak, remaja, dewasa dan lansia, perilaku merokok tidak memandang jenis kelamin bahkan berdasarkan hasil riskesdas perilaku merokok yang kenaikannya sangat besar terjadi pada perempuan. Perilaku merokok ini sangat membahayakan kesehatan maka dari itu perlu dilakukan sebuah upaya untuk mengurangi perilaku merokok maupun dampak yang ditimbulkan akibat rokok baik bagi perokok aktif maunpun perokok pasif. Upaya yang dilakukan dalam pengabdian masyarakat adalah upaya promotif yaitu penyuluhan KUTARO (lingkungan tanpa rokok) dengan tujuan untuk meningkatkan kesadaran masyarakat untuk peduli terhadap kesehatan dan lingkungan, upaya selanjutnya yaitu upaya preventif seperti penanaman lidah mertua yang berfungsi untuk mengikat radikal bebas yang berasal dari asap rokok yang ada di udara, dan demo pembuatan pudding mangga yang memiliki kandungan antioksidan, dimana antioksidan dapat mengikat radikal bebas yang masuk ke tubuh supaya tidak merusak organ dan kegiatan ini juga bermanfaat untuk menambah usaha masyarakat sehingga ada peningkatan status ekonomi.
\end{abstract}

Kata Kunci: Rokok, Promotif, Preventif

\section{ABSTRACT}

Smoking has become a necessity and lifestyle of the people of Indonesia, cigarettes cause many problems for smokers themselves are even more risky for people who do not smoke but inhale cigarette smoke (passive smokers). The problem of smoking in Indonesia is still a concern of the government, but the high number of smokers starting from children, adolescents, adults and the elderly, smoking behavior does not look at gender even based on the results of risk smoking behavior that a very large increase occurred in women. This smoking behavior is very dangerous to health and therefore needs to be done an effort to reduce smoking behavior and the effects caused by smoking for both active smokers and passive smokers. Efforts made in community service are promotive efforts, namely counseling KUTARO(Lingkungan Tanpa Rokok/Environment Without Cigarettes) with the aim to increase public awareness to care for health and the environment, further efforts are preventive efforts such as planting in-law's tongue which functions to bind free radicals originating from cigarette smoke in the air, and the demonstration of making mango pudding that has antioxidant content, where antioxidants can bind free radicals that enter the body so as not to damage organs and this activity is also beneficial to increase community efforts so that there is an increase in economic status.

Keywords: cigarette, promotive, preventive 


\section{PENDAHULUAN}

Perilaku merokok dikalangan masyarakat Indonesia sudah menjadi bagian dari kehidupan sehari-hari, dimana perilaku merokok ini dipengaruhi oleh adanya media masa yang mengiklankan orang merokok itu merupakan laki-laki sejati, dipengaruhi juga oleh teman sebaya bahkan terpengaruh karena melihat orang tua merokok di rumah. Perilaku merokok sangat berisiko terhadap kesehatan bahkan risiko dari asap rokok lebih besar terjadi pada orang yang tidak merokok tapi terkena asap rokok (perokok pasif). Satu batang rokok mengandung lebih 4.000 racun di dalamnya seperti nikotin, tar, formaldehida, kadmium, hidrogen sianida dimana zat ini bersifat adiktif dan karsinogenik yang dapat menyebabkan terjadinya aterosklorosis, COPD (Chronic Obstructive Pulmonary Disease), peningkatan stres oksidatif dan berkurangnya antioksidan yang ada di dalam tubuh [1],[2],[3].

Masyarakat RW 05 Kelurahan Rancamaya memiliki kebiasaan merokok yang dimulai dari anak-anak sampai orang dewasa dan terjadi juga pada perempuan yang dimana perilaku merokok identik dengan laki-laki. Kebiasaan merokok terjadi di luar rumah dan dalam rumah dimana masyarakat memiliki anak balita, ibu hamil, ibu menyusui yang memiliki risiko lebih besar apabila menghirup asap rokok. Hal ini sangat memprihatinkan karena risiko yang akan diderita oleh masyarakat tersebut.
Risiko yang ditimbulkan oleh rokok perlu diminimalisir dengan sebuah upaya promotif dan preventif. Upaya promotif yang perlu dilakukan adalah edukasi (promosi kesehatan) kepada masyarakat yang merokok maupun tidak merokok karena risiko yang ditimbulkan oleh rokok bukan hanya pada yang merekok saja, namun orang yang tidak merokok juga perlu diedukasi terkait risiko terhirup asap rokok dari lingkungan. edukasi ini sangat penting dilakukan karena menambah pengetahuan bagi masyarakat untuk meraih hidup sehat dengan cara mempengaruhi perilaku baik secara kelompok maupun individu dengan pesan yang disampaikan kepada masyarakat [4],[5].

Upaya yang perlu dilakukan selain perubahan perilaku masyarakat perlu juga dilakukan sebuah upaya preventif seperti penanaman lidah mertua (Sanseveria) yang berfungsi untuk menyerap zat adiktif yang dikeluarkan dari asap rokok berada di udara seperti kadmium (cd), co, formaldehida. Lidah mertua dapat menetralisir lingkungan udara yang berada di luar rumah maupun dalam rumah, sehingga dapat mengurangi udara yang tercemar oleh asap rokok [6],[7],[8].

Kegiatan preventif selanjutnya adalah demo masak pudding mangga yang kaya akan antioksidan, dimana antioksidan ini dapat menangkal radikal bebas yang berasal dari asap rokok masuk ke dalam tubuh sehingga dapat mengurangi kerusakan organ tubuh [9]. Selain sebagai upaya preventif 
demo masak pudding mangga ini juga bermanfaat untuk ladang usaha bagi masyarakat sebagai penambah pendapatan.

\section{METODE PELAKSANAAN KEGIATAN}

Tempat dan Waktu. Kegiatan upaya promotif dan preventif untuk mengurangi dampak yang ditimbulkan dari rokok dilaksanakan di wilayah kerja Puskesmas Cipaku Kelurahan Rancamaya RW 05 Bogor Jawa Barat yang dilaksanakan dari tanggal 23 September - 01 November 2019.

Khalayak Sasaran. Khalayak sasaran dalam kegiatan ini adalah masyarakat baik yang perokok aktif maupun perokok pasif yang memiliki risiko kesehatan ditimbulkan akibat asap rokok, yang berada di RW 05 .

Metode Pengabdian. Pengabdian dilakukan dengan tahapan yaitu :

1. Analisis Situasi dan Persiapan

Pelaksanaan kegiatan dimulai dari analisis situasi di RW 05 terkait perilaku merokok dan malakukan persiapan kegiatan upaya promotif dan preventif yang akan dilakukan.

2. Penyuluhan KUTARO (Lingkungan

Tanpa Rokok) dan Simulasi Dampak

Rokok dengan Media Kapas.

Penyuluhan KUTARO dan simulasi dampak rokok menggunakan media kapas dilakukan pada tanggal 18 oktober 2019 yang beralokasi di RW 05 .

3. Penanaman Lidah Mertua

Kegiatan penanaman lidah mertua dilakukan pada di RW 05 Kelurahan Rancamaya
4. Demo Masak Pudding Mangga

Kegiatan demo masak pudding mangga dilakukan pada tanggal 31 oktober 2019 yang beralokasi di RW 05 Kelurahan Rancamaya.

Indikator Keberhasilan. Indikator keberhasilan kegiatan upaya promotif dan preventif adalah

1. Meningkatnya pemahaman masyarakat terkait perilaku merokok dan bahaya yang ditimbulkan oleh rokok.

2. Meningkatkan minat masyarakat untuk melakukan sebuah upaya preventif untuk menanggulangi bahaya rokok.

3. Menambah keterampilan masyarakat untuk pengolahan makanan

4. Menambah pendapatan masyarakat dalam bidang usaha olahan makanan.

Metode Evaluasi. Metode evaluasi dilakukan secara monitoring setelah dilakukan penyuluhan untuk melihat perubahan perilaku merokok. Sedangkan tahapan evaluasi dilakukan pada saat kegiatan berjalan dan akhir kegiatan. Evaluasi kegiatan dikatakan sukses apabila ada perubahan perilaku merokok apabila :

1. Masyarakat tidak merokok di dalam rumah

2. Masyarakat mengurangi konsumsi rokok

3. Masyarakat ikut menanam lidah mertua

4. Masyarakat mengkonsumsi buah seperti mangga.

\section{HASIL DANPEMBAHASAN}

Hasil yang dicapai dalam kegiatan pengabdian masyarakat yang dilakukan di 
RW 05 Kelurahan Rancamaya Wilayah Kerja Puskesmas Cipaku adalah:

\section{Penyuluhan KUTARO (Lingkungan Tanpa Rokok) dan Simulasi Dampak Rokok dengan Media Kapas}

Kegiatan penyuluhan dilaksanakan pada tanggal 18 Oktober 2019 di RW 05 di rumah kader RT 01 yang dihadiri oleh masyarakat setempat baik laki-laki maupun perempuan sebanyak 28 orang yang terdiri dari ketua RW 05, Ketua RT 01, Ketua RT 02, Kader, Ketua Pemuda dan masyarakat, proses penyuluhan dilakukan dengan cara penyampaian materi tentang rokok bahaya yang ditimbulkan oleh rokok dengan tujuan untuk merubah perilaku masyarakat supaya bisa meraih hidup yang lebih sehat dan dilakukan simulasi dampak rokok dengan media kapas. Masyarakat sangat antusias ketika simulasi dilakukan karena masyarakat dapat melihat secara langsung bagaimana proses sebuah kapas tercemar oleh asap rokok dalam waktu yang singkat.

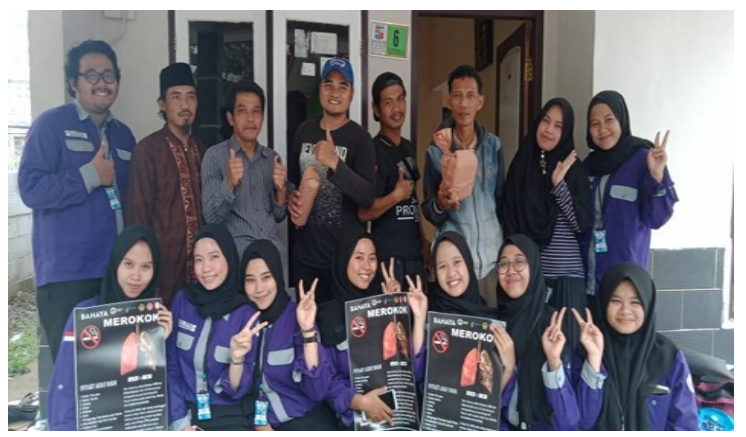

Gambar 1. Penyuluhan Kutaro

Masyarakat lebih memahami ketika dilakukan simulasi dampak rokok sehingga ada perubahan yang terjadi di masyarakat, dimana pada sebelum dilakukan penyuluhan KUTARO dan simulasi masyarakat masih merokok di dalam rumah tapi sekarang masyarakat merokok pada satu tempat dan mulai mengurangi rokok yang dihisap dalam satu hari.

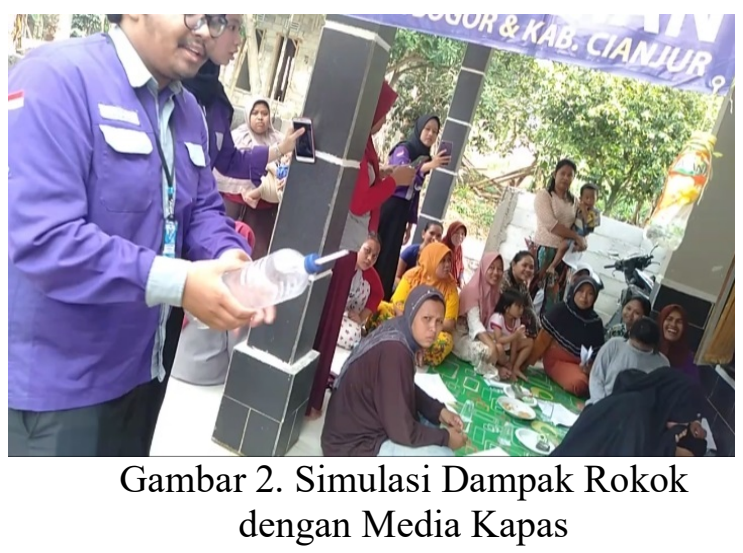

\section{Penanaman Lidah Mertua (Sanseveria)}

Kegiatan penanaman lidah mertua dilakukan pada hari Rabu tanggal 23 oktober 2019 dibeberapa tempat wilayah RW 05 bersama ketua RT 01 dan kader. Masyarakat baru mengetahui bahwa lidah mertua dapat menyerap zat adiktif yang dikeluarkan oleh asap rokok sehingga bisa mengurangi pencemaran udara baik di dalam rumah maupun luar rumah. Masyarakat ikut berpartisipasi menanam lidah mertua bukan hanya di lingkungan rumah saja tapi ditanam juga di sebuah posko tempat masyarakat merokok.

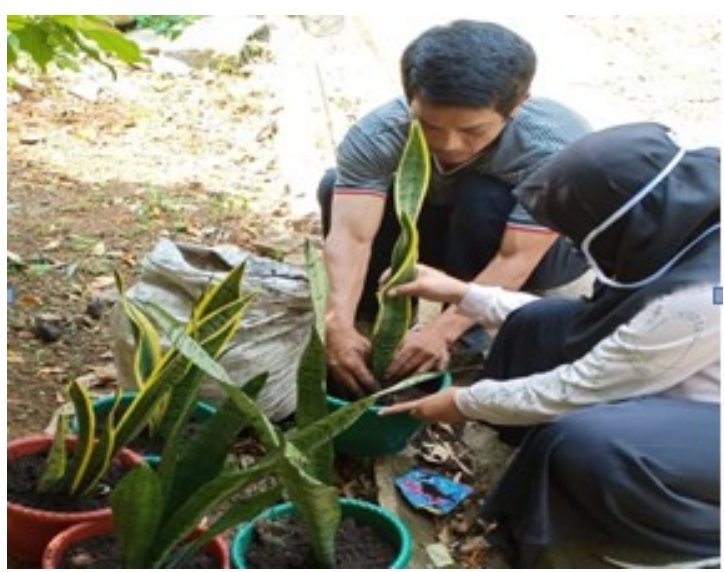

Gambar 3. Penanaman Lidah Mertua 


\section{Demo Masak Pudding Mangga}

Demo masak dilakukan pada tanggal 31 oktober 2019 di salah satu rumah warga, buah mangga dipilih karena banyak tersedia di pasaran dengan harga yang murah tapi kaya akan antioksidan, kegiatan ini bukan hanya mengajarkan masyarakat mengkonsumsi buah setiap harinya, namun mengajarkan masyarakat tentang inovasi pengolahan bahan makanan, proses pengolahan yang dapat mengurangi risiko hilang atau berkurangnya kandungan zat gizi pada buah, mengedukasi masyarakat juga bahwa kandungan antioksidan yang ada pada buah mangga tersebut dapat mengikat radikal bebas di dalam tubuh yang berasal dari asap rokok dan demo masak pudding mangga ini juga bisa amenjadi peluang usaha untuk menambah peningkatana pendapatan masyarakat.

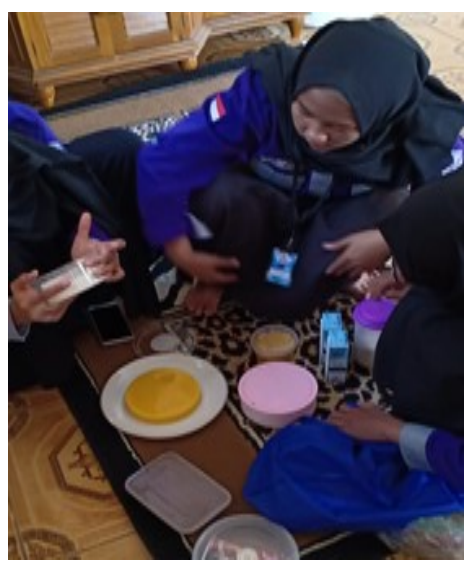

Gambar 4. Demo Masak Puding Mangga

Keberhasilan Upaya Promotif dan Preventif untuk Mengurangi Risiko yang Ditimbulkan oleh Rokok

Kegiatan pengabdian masyarakat ini dikatakan berhasil dilihat dari ouput atau perubahan yang dilakukan oleh masyarakat RW 05 Kelurahan Rancamaya wilayah kerja
Puskesmas Cipaku adalah masyarakat yang merokok sudah tidak merokok di dalam rumah, karena masyarakat sudah memahami risiko apabila merokok di dalam rumah yang dapat membahayakan kesehatan anggota keluarga terutama bayi, balita dan ibu hamil. Masyarakat masih melakukan perilaku merokok namun sudah difokuskan untuk kegiatan merokok pada satu tempat dan ditempat tersebut ditanam lidah mertua yang dapat membersihkan udara yang tercemar akibat rokok tersebut. Masyarakat sudah mulai mengkonsumsi buah yang diterapkan dalam setiap kegiatan di masyarakat ada menu buah yang tersedia.

\section{KESIMPULAN}

Pelaksanaan kegiatan pengabdian masyarakat dalam upaya promotif dan preventif untuk mengurangi risiko yang ditimbulkan oleh rokok di RW 05 Kelurahan Rancamaya terlaksana dengan baik dan mendapatkan perhatian dari pihak Kelurahan maupun Puskesmas setempat. Hasil dari serangkaian kegiatan ini berdampak terhadap peningkatan pengetahuan masyarakat terhadap bahaya yang ditimbulkan dan adanya perubahan perilaku, kegiatan ini juga menambah keterampilan Ibu-Ibu dalam pengolahan bahan makanan yang dapat menangkal radikal bebas yang diakibatkan oleh asap rokok dan juga menjadi ladang usaha untuk menambah penghasilan.

\section{SARAN}

Pengabdian masyarakat ini bisa dikembangkan lagi dengan mengembang 
berbagai produk buah maupun sayur yang kaya akan antioksidan sehingga dapat menetralisir asap rokok seperti pembuatan teh dari kulit buah naga maupun edukasi secara berkelanjutan dengan menggunakan media video atau edukasi permainan.

\section{UCAPAN TERIMAKASIH}

Penulis mengucapkan terimakasih kepada keluarga besar Universitas Ibn Khaldun Bogor khususnya Program Studi Kesehatan Masyarakat yang telah memberikan kesempatan kepada penulis untuk melakukan rangkaian tri dharma perguruan tinggi yaitu pengabdian kepada masyarakat. Terimakasih juga kepada mahasiswa program studi kesehatan masyarakat yang telah membantu kegiatan pengabdian ini dan kepada masyarakat RW 05 Kelurahan Rancamaya wilayah kerja Puskesmas Cipaku yang telah memberikan kesempatan kepada penulis untuk melakukan serangkaian kegiatan pengabdian masyarakat.

\section{REFERENSI}

[1] Rahmadi, A., Lestari, Y., Yenita. 2013. Hubungan Pengetahuan dan Sikap Terhadap Rokok Dengan Kebiasaan Merokok Siswa SMP di Kota Padang. J Kesehat Andalas, 2(1)

[2] Kurniati, I.D., Rohmani, A. 2017. Ekstrak Buah Kersen (Muntingia calabura) dalam Menurunkan Jumlah Sel Goblet pada Tikus yang Dipapar
Asap Rokok. J. Kedokt dan Kesehat, 12(2)

[3] Nasution, A.S., Wirjatmadi, B., Adriani, M. 2016. Efek Preventif Pemberian Ekstrak Kulit Buah Naga Berdaging Super Merah (Hylocereus Costaricensis) terhadap Malondialdehid Tikus Wistar yang Dipapar Asap Rokok. J Kedokt Brawijaya, 29(1):21-4

[4] Lenggono, K.A. 2016. Hubungan Pengetahuan Remaja Perokok tentang Rokok dengan Perilaku Merokok di SMA N 01 Singosari, Malang. $J$. Kesehat Hesti Wira Sakti, 3(3):75-80

[5] Alamsyah, A., Nopianto. 2017. Determinan Perilaku Merokok pada Remaja. J. Endur, 2(1):25-30

[6] Mubarok, Y., Winanti, S., Nurcahyo, E.A.D. 2012. Pengaruh Lama Adsorbsi Ekstrak Sanseveria (Lidah Mertua) Sebagai Adsorben Logam Ag Dari Limbah Industri Perak Di Kotagede. Pelita, $7(2$

[7] Adawiyah, A.R., Arindita, N.D., Selviastuti, R., Yuliawati, S. 2013. Panda Sanseveria (Pengharum Ruangan Anti Debu dan Asap Rokok dengan Sistem Penetralisir Sirkulasi Udara. J. Ilm Mhs, 2(1)

[8] Jaswiah, Syarifudin, S.H., Novianti, I. 2016. Fitoremediasi Logam Kadmium pada Asap Rokok Menggunakan Tanaman Lidah Mertua Jenis Sansevieria Hyacinthoides dan Sansevieria Trifasciata. Chim Nat Acta, 4(2):88-92

[9] Nadimin. 2018. Pengaruh Kebiasaan Konsumsi Sayur, Buah dan Perokok Pasif terhadap Kapasitas Antioksidan Total Ibu Hamil. J. MKMI, 1(2) 